Muhamad Ferdian Saputra ${ }^{*}$, Muhammad Firdaus ${ }^{2}$, Tanti Novianti ${ }^{2}$ IInstitut Pertanian Bogor dan Badan Pusat Statistik, Simboro, Mamuju, Indonesia

Institut Pertanian Bogor, Darmaga, Bogor, Indonesia

*) Email korespondensi: ferdian1001@gmail.com
AGRARIS: Journal of Agribusiness and Rural Development Research

Vol. 5 No. 2 Juli-Desember 2019

\section{Pola Konsumsi Pangan Non Karbohidrat pada Provinsi Tahan dan Rawan Pangan (Provinsi Kalimantan Timur dan Nusa Tenggara Timur) Tahun 2017}

\section{Consumption Patterns of Non Carbohydrate Food in Secure and Insecure Provinces (East Kalimantan and East Nusa Tenggara Province) in 2017}

DOI: http://dx.doi.org/10.18196/agr.5282

\begin{abstract}
The problem of national food security could not be resolved if the problems at the lowest level (household) did not resolved. One of the effective strategy to achieve food security was increasing food diversification. This study compared the patterns of consumption and the level of diversification of household food among provinces that were resistant to food insecurity. This study used National Socio-Economic Survey (Survei Sosial Ekonomi Nasional/SUSENAS) data from Statistic Indonesia and analyzed using the Berry index and the Almost Ideal Demand System (LA / AIDS) model. This study found that the level of income and the level of food diversification in food secure province (East Kalimantan) were higher than those in food insecure province (East Nusa Tenggara). The patterns of household food consumption in East Nusa Tenggara province was more influenced by changes in income, while East Kalimantan was subject to price changes.
\end{abstract}

Keywords: Diversification, Elasticity, Income, $L A / A I D S$, Price.

\section{INTISARI}

Permasalahan ketahanan pangan nasional tidak dapat diselesaikan apabila permasalahan di tingkat terkecil (rumahtangga) tidak terselesaikan. Salah satu strategi yang efektif untuk menuju ketahanan pangan adalah dengan melakukan peningkatan diversifikasi pangan. Penelitian ini membandingkan pola konsumsi dan tingkat diversifikasi pangan rumah tangga antara provinsi tahan dengan rawan pangan. Penelitian ini menggunakan data SUSENAS dan dianalisis menggunakan indeks Berry dan model Linear Almost Ideal Demand System (LA/AIDS). Penelitian ini menemukan bahwa tingkat pendapatan dan tingkat diversifikasi pangan di provinsi tahan pangan (Kalimantan Timur/Kaltim) lebih tinggi dibandingkan dengan provinsi yang rawan pangan (Nusa Tenggara Timur/NTT). Pola konsumsi pangan rumah tangga di NTT lebih dipengaruhi oleh perubahan pendapatan, sedangkan Kaltim oleh perubahan harga.

Kata kunci : diversifikasi, elastisitas, harga, LA/AIDS, pendapatan

\section{PENDAHULUAN}

Pangan merupakan salah satu kebutuhan mendasar bagi manusia. Sektor pangan memiliki keterikatan ke depan yang cukup tinggi dibandingkan dengan sektor lainnya (Fortunika et al., 2017). Permasalahan pangan nasional tidak dapat diselesaikan apabila permasalahan di tingkat terkecil (rumah tangga) tidak terselesaikan. Ketersediaan pangan yang cukup sudah menjadi hak asasi bagi setiap warga Negara. Kebijakan penyediaan pangan dapat disusun dengan menggunakan informasi pola konsumsi rumah tangga (Kementerian Perdagangan, 2013).

Pola konsumsi pangan masyarakat Indonesia masih belum beragam dan bergizi seimbang, di mana pola konsumsi pangan pokok per kapita masih didominasi oleh makanan sumber karbohidrat 
(Rachman dan Ariani,2008). Pola Pangan Harapan (PPH) Indonesia juga belum mencapai angka yang ideal, di mana angka kecukupan energi (AKE) penduduk di Indonesia memiliki skor 90.4 kkal pada tahun 2017. Pendapat lain dipaparkan oleh Ariani (2010) yang menemukan bahwa pola konsumsi masyarakat Indonesia mulai beragam, khusunya untuk konsumsi protein yang sudah melebihi dari anjuran, namun untuk konsumsi umbi-umbian, pangan hewani, sayur, dan buah masih harus ditingkatkan.

Faktor harga pangan yang tidak stabil juga menjadi permasalahan bagi rumah tangga. Harga pangan menentukan pendapatan riil masyarakat secara positif bagi pedagang pangan dan secara negatif bagi pembelinya yang akan memengaruhi distribusi pendapatan dan investasi, sehingga memengaruhi terjadinya kemiskinan yang juga memengaruhi akses rumah tangga untuk memperoleh makanan (Matz et al. 2015). Penelitian Riyani et al. (2018) juga menyatakan bahwa peningkatan harga komoditas pangan pertanian dapat menyebabkan menurunnya permintaan komoditas tersebut.

Menurut UU No. 18 Tahun 2012 tentang pangan yang menyatakan bahwa penyelenggaraan pangan dilakukan berdasarkan asas kedaulatan, kemandirian, ketahanan, keamanan, manfaat, pemerataan, berkelanjutan, dan berkeadilan. Penyelenggaraan pangan yang diamanatkan oleh undang-undang tersebut didorong untuk mewujudkan kedaulatan pangan, kemandirian pangan, dan ketahanan pangan. Ketersediaan dan keterjangkauan/akses dalam memperoleh pangan yang cukup menjadi indikator penting dalam ketahanan pangan. Strategi pencapaian ketahanan pangan biasanya dilakukan dengan pengembangan komoditas pangan baik dari kuantitas dan kualitasnya. Penelitian Wijaya (2017) menemukan bahwa pengembangan komoditas pangan unggulan dapat meningkatkan produktivitas yang bisa menunjang ketahanan pangan. Strategi lainnya yang dapat dijadikan alternatif adalah dengan melakukan diversifikasi pangan.

Ketika terjadi kenaikan harga barang, diversifikasi pangan menjadi salah satu cara untuk mengatasi ketergantungan terhadap pangan tertentu.
Diversifikasi pangan tidak hanya fokus pada pemenuhan kebutuhan pangan sumber karbohidrat saja, namun juga pada sumber makanan lainnya baik protein, vitamin, dan mineral. Ruel (2003) mendefinisikan bahwa diversifikasi pangan merupakan jumlah atau jenis pangan yang berbeda yang dikonsumsi pada suatu periode tertentu. Hal ini menunjukkan bahwa untuk memperoleh makanan yang sehat dengan gizi seimbang, rumah tangga harus mengkonsumsi makanan yang berbeda. Pernyataan tersebut mengandung arti bahwa konsumsi makanan sumber non karbohidrat menjadi sangat penting.

Faktor pendapatan juga turut memengaruhi ketahanan pangan rumahtangga. Naiknya pendapatan perkapita menunjukkan peningkatan akses terhadap pangan yang seharusnya diiringi dengan peningkatan diversifikasi pangan, sehingga perlu penelitian untuk membuktikan apakah dengan peningkatan akses terhadap pangan menyebabkan peningkatan diversifikasi pangan rumah tangga di Indonesia. Penelitian Kumar et al. (2011) membuktikan bahwa peningkatan pendapatan mengakibatkan pengalihan alokasi anggaran penduduk dari makanan berbasis sereal/biji-bijian menuju komoditas bernilai tinggi seperti buah-buahan, sayuran, susu, ikan, daging dan produk daging. Hasil berbeda ditemukan oleh Widodo et al. (2016) menemukan bahwa tingkat pendapatan tidak berdampak pada tingkat kerawanan pangan.

Informasi pola konsumsi juga dapat digunakan oleh pemerintah untuk memantau tingkat kesejahteraan penduduk yang diukur dengan tingkat konsumsi pangan secara kuantitas (Kementerian Perdagangan dalam Analisis Dinamika Konsumsi Pangan Masyarakat Indonesia tahun 1996-2011, 2013). Kenaikan harga pangan yang tidak terkontrol dalam jangka pendek akan menyebabkan kemampuan akses masyarakat untuk memperoleh makanan menjadi berkurang sehingga dapat menyebabkan terjadinya kemiskinan (Headey et al.2016).

Periode 2017 sampai dengan 2018 ada 5 (lima) komoditas strategis yang konsisten menyebabkan kenaikan harga pangan di NTT yaitu jagung, daging ayam ras, tongkol, tempe dan minyak 
goreng Adapun di Kaltim yaitu ketela pohon, mie instant, telur ayam ras, pisang, dan minyak goreng.

TABEL 1. ANDIL INFLASI DARI KOMODITAS PANGAN, 2017-2018

\begin{tabular}{lrrrc}
\hline \multirow{2}{*}{ Nama Komoditas } & \multicolumn{3}{c}{2017} & \multicolumn{2}{c}{2018} \\
\cline { 2 - 5 } & NTT & Kaltim & NTT & Kaltim \\
\hline Beras & $-0,02$ & - & 0,18 & 0,05 \\
Jagung & 0,01 & $-0,01$ & 0,01 & 0,01 \\
Ketela Pohon & - & 0,02 & 0,01 & 0,01 \\
Mie Instant & $-0,01$ & 0,02 & 0,01 & 0,01 \\
Terigu & $-0,01$ & $-0,01$ & 0,01 & $-0,01$ \\
Daging Ayam Ras & 0,05 & $-0,09$ & 0,38 & 0,06 \\
Daging Sapi & $-0,01$ & 0,02 & 0,01 & $-0,03$ \\
Tongkol & 0,07 & 0,06 & 0,03 & $-0,08$ \\
Telur Ayam Ras & 0,09 & 0,07 & $-0,01$ & 0,05 \\
Tahu & 0,04 & $-0,02$ & $-0,07$ & $-0,01$ \\
Tempe & 0,02 & $-0,04$ & 0,01 & 0,01 \\
Apel & 0,02 & $-0,03$ & $-0,02$ & 0,03 \\
Pisang & $-0,03$ & 0,01 & $-0,02$ & 0,07 \\
Bawang Merah & $-0,30$ & $-0,23$ & $-0,08$ & 0,04 \\
Cabai Merah & $-0,10$ & $-0,08$ & 0,03 & $-0,01$ \\
Minyak Goreng & 0,04 & 0,02 & 0,02 & 0,01 \\
\hline Sumber : BPS (2017-2018) & & & &
\end{tabular}

Perbedaan keadaan pembangunan di masingmasing wilayah di Indonesia menyebabkan perbedaan rumah tangga dalam melakukan diversifikasi pangan. Wilayah Indonesia bagian timur rata-rata merupakan daerah rawan pangan dibandingkan dengan provinsi di kawasan lainnya.

Berdasarkan data pengeluaran konsumsi BPS Maret 2017, terdapat 16 Provinsi yang memiliki ratarata pengeluaran di atas angka nasional salah satunya adalah Kaltim (disebut sebagai provinsi tahan pangan) sebesar 1,443,928 rupiah, sedangkan provinsi dengan rata-rata pengeluaran terendah yaitu NTT (disebut sebagai provinsi rawan pangan) sebesar 681,484 rupiah. Kaltim merupakan provinsi yang memiliki pangsa pengeluaran pangan yang terendah diluar pulau Jawa dan Bali sedangkan NTT memiliki pangsa pengeluaran pangan tertinggi.

Menurut Peta Ketahanan dan Kerawanan Pangan atau Food Security and Vulnerability Atlas (FSVA) Badan Ketahanan Pangan tahun 2017 menunjukkan bahwa Kaltim merupakan provinsi dengan ketahanan pangan yang baik, sedangkan NTT termasuk dalam kategori provinsi yang rawan pangan (Gambar 1)

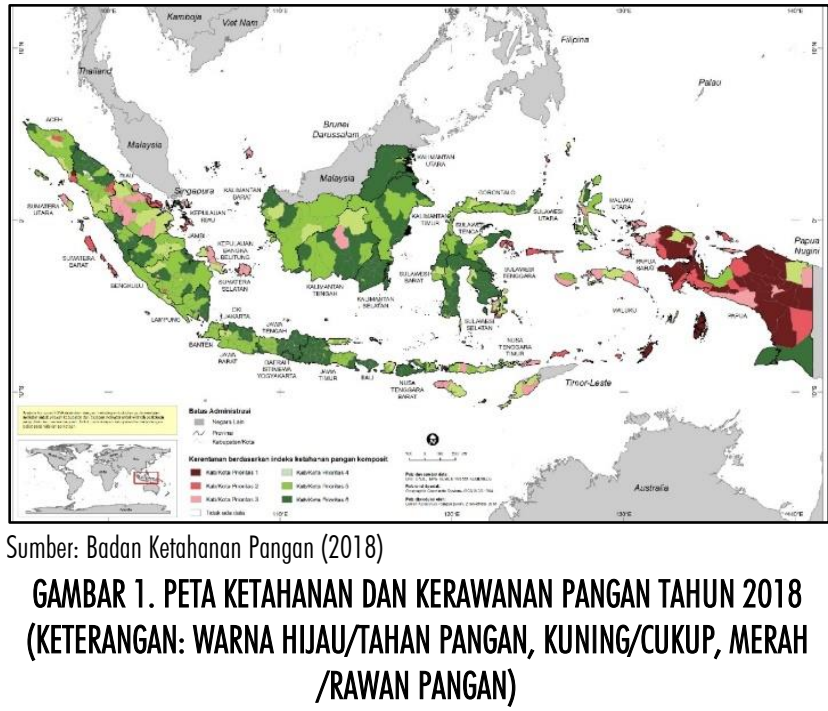

Penelitian terhadap komoditas pangan sumber non karbohidrat baik tingkat provinsi maupun nasional di Indonesia antara lain dilakukan oleh Arthatiani et al. (2018), Irawan (2002), Mauludyani et al. (2008), Miranti et al.(2016), Pangaribowo et al.(2011), Rizal et al. (2018), dan Suroso et al. (2014). Namun penelitian-penelitian sebelumnya hanya melakukan pengamatan pada skala provinsi dengan unit sampel rumah tangga golongan tertentu saja, atau skala nasional dengan unit sampel provinsi, atau hanya pada nilai total kelompok komoditas saja. Penelitian yang membandingkan antara daerah rawan dan tahan pangan masih terbatas. Informasi ini dapat berguna untuk merumuskan kebijakan intervensi pangan yang dirancang untuk meningkatkan konsumsi golongan rumah tangga di daerah rawan pangan serta meningkatkan diversifikasi pangan di provinsi tahan dan rawan pangan. Hal tersebut penting bagi pengambil kebijakan, karena komoditas yang diintervensi hanya dikonsumsi oleh golongan yang menjadi target sasaran kebijakan (Timmer, 1983).

Penelitian ini bertujuan untuk menganalisis perbedaan pola konsumsi dan tingkat diversifikasi pangan rumah tangga antara provinsi tahan dengan rawan pangan. Studi ini juga mengkaji perbedaan pengaruh pendapatan dan harga pangan terhadap diversifikasi pangan rumah tangga. 


\section{METODE PENELITIAN}

Penelitian ini menggunakan data sekunder yaitu SUSENAS Modul Konsumsi bulan Maret tahun 2017. Unit sampel dalam penelitian adalah sebanyak jumlah sampel Susenas tahun 2017 dengan rincian sebagai berikut: sebanyak 5,134 rumah tangga untuk Kaltim, dan 10,795 rumah tangga untuk NTT.

Komoditas yang digunakan yaitu 15 komoditas pangan sumber non karbohidrat yang terdiri dari 9 komoditas strategis dan 6 komoditas lainnya yang banyak dikonsumsi di kedua provinsi. Komoditas strategis ini juga terdiri dari komoditas strategis di tingkat individu dan tingkat grosir. Adapun rincian komoditas sebagai berikut:

1. Komoditas strategis di tingkat individu yaitu kedelai, bawang merah, cabai merah keriting, telur ayam ras, daging ayam ras dan daging sapi;

2. Komoditas strategis di tingkat grosir yaitu gula, minyak goreng,;

3. Komoditas lainnya yaitu ikan tongkol, tahu, tempe, apel, pisang, vetsin, mie instan.

Analisis dilakukan berdasarkan penggolongan tipe daerah dan pengeluaran rumah tangga perkapita per bulan (Tabel 2). Tipe daerah adalah berdasarkan daerah perkotaan dan perdesaan. Penggolongan berdasarkan pengeluaran rumah tangga perkapita dilakukan mengikuti penggolongan yang digunakan oleh BPS dan diberikan kode untuk memudahkan analisis, sebagai berikut:

TABEL 2. KODE GOLONGAN PERKAPITA SEBULAN

\begin{tabular}{cc}
\hline $\begin{array}{c}\text { Golongan Pengeluaran perkapita Sebulan } \\
\text { (Rupiah) }\end{array}$ & Keterongan \\
\hline$<150,000(G 1)$ & Golongan 1 \\
$150,000-199,999(62)$ & Golongan 2 \\
$200,000-299,999(G 3)$ & Golongan 3 \\
$300,000-499,999(64)$ & Golongan 4 \\
$500,000-749,999(65)$ & Golongan 5 \\
$750,000-999,999(66)$ & Golongan 6 \\
$1,000,000-1,499,999(67)$ & Golongan 7 \\
$\geq 1,500,000(68)$ & Golongan 8 \\
\hline Sumber : BPS diolah (2017) &
\end{tabular}

Pada tahap awal analisis dilakukan secara statistik deskriptif melalui penyajian nilai konsumsi pangan sumber non karbohidrat berdasarkan pada pangsa pengeluarannya. Teknik analisis yang sama juga telah dilakukan pada beberapa penelitian sebelumnya mengenai pola konsumsi antara lain Mauludyani et al. (2008), Miranti et al. (2016), dan Arthatianiet al. (2018). Hasil tabulasi dari analisis pola konsumsi kemudian digunakan untuk membentuk variabel pada model permintaan pangan yang diduga dalam penelitian.

Metode analisis yang digunakan dalam penelitian ini adalah model Linear Aproximation Almost Ideal Demand System (LA/AIDS) yang merupakan modifikasi model yang dikembangkan oleh Deaton dan Muelbauer (1980) dengan memasukkan berbagai variabel yang secara teoritis dan empiris relevan mempengaruhi permintaan. Beberapa kelebihannya yaitu: (1) memberikan kuasa pada pendekatan orde pertama untuk setiap sistem permintaan, (2) memenuhi aksioma pilihan dengan tepat, (3) mengagregasi sempurna para konsumen tanpa melibatkan kurva linear Engel paralel, (4) memiliki bentuk fungsional yang konsisten dengan data anggaran rumah tangga, (5) mudah untuk diestimasi, dapat menghindari kebutuhan untuk estimasi non linear, dan (6) dapat digunakan untuk menguji pembatasan homogenitas dan simetri melalui pembatasan linear pada parameter tetap (Deaton dan Muellbauer 1980). Dipilihnya model ini karena telah digunakan dalam berbagai penelitian sebelumnya Faharuddin et al. (2015), Miranti et al. (2016), dan Surianiet al. (2018) dan mampu memberikan hasil yang baik saat diaplikasikan dengan data di Indonesia. Fungsi permintaan AIDS dalam bentuk budget share yang digunakan dalam penelitian yaitu:

$\mathrm{W}_{\mathrm{i}}=\alpha_{\mathrm{i}}+\sum_{\mathrm{j}} \gamma_{\mathrm{ij}} \log \left(\mathrm{p}_{\mathrm{j}}\right)+\beta_{\mathrm{i}} \log \left\{\frac{\mathrm{x}}{\mathrm{p}^{*}}\right\}+\theta$ art $+\mu \log \exp +\lambda \mathrm{dwil}+\delta \mathrm{imr}_{\mathrm{i}}(1)$

Keterangan:

$\mathrm{W}_{\mathrm{i}}$

: Budget share pangan i

$\mathrm{p}_{\mathrm{j}} \quad$ : Harga pangan ke-j

$\mathrm{x} \quad$ : Total pengeluaran pangan

$\mathrm{P}$

: Indeks harga stone

$\alpha_{\mathrm{i}}, \beta_{\mathrm{i}}, \gamma_{\mathrm{ij}}, \theta, \mu, \lambda, \delta \quad:$ intersep, parameter dugaan harga pangan, total pengeluaran, jumlah anggota rumah tangga, dummy 
wilayah, dan inverse mills ratio

$\exp$

: Pengeluaran/pendapatan rumah tangga

dwil : dummy desa kota

imri

: inverse mills ratio

Dari Persamaan 1 dihasilkan 15 persamaan operasional untuk setiap provinsi. Contoh persamaan umum untuk komoditas ikan tongkol adalah sebagai berikut:

$\mathrm{W}_{\text {tong }}=\alpha_{\text {tong }}+\gamma_{\text {tong }} \log \mathrm{p}_{\text {tong }}+\gamma_{\text {dsap }} \log \mathrm{p}_{\text {dsap }}+\ldots+\gamma_{\text {rok }} \log \mathrm{p}_{\text {rok }}+\beta_{\text {tong }} \log$ $\left\{\frac{x}{p}\right\}+\theta \operatorname{art}_{j}+\mu \log \exp +\lambda \operatorname{dwil}^{+} \delta \operatorname{imr}_{\mathrm{i}}(2)$

Setelah memperoleh model permintaan pangan LA/AIDS maka dapat dianalisis lebih lanjut untuk memperoleh besaran nilai elastisitas pengeluaran, elastisitas harga dan elastisitas harga silang untuk dapat menggambarkan respon permintaan terhadap berbagai perubahan yang terjadi dalam variabel.

Model permintaan dikatakan sesuai teori jika memenuhi syarat-syarat yang harus dipenuhi pada fungsi permintaan. Oleh karena itu, model yang digunakan adalah model permintaan pangan dengan restriksi adding up, homogenitas, dan simetri. Nilai koefisien determinasi yang cukup tinggi yaitu 55 persen, sisanya dijelaskan oleh faktor lain di luar model.

\section{HASIL DAN PEMBAHASAN \\ PANGSA PENGELUARAN PANGAN}

Berdasarkan pengolahan data maka dapat diketahui komoditas sumber non karbohidrat dengan pangsa pengeluaran tertinggi adalah gula pasir di NTT sedangkan Kaltim adalah daging ayam ras. Pangsa pengeluaran gula pasir di NTT adalah 0,04 sedangkan daging ayam ras di Kaltim sebesar 0,06 (Tabel 3). Dari data tersebut juga dapat dilihat bahwa NTT memiliki ketahanan pangan yang lebih rendah dikarenakan pangsa pengeluaran pangan non karbohidrat lebih rendah dibandingkan dengan Kaltim.

Analisis model permintaan LA/AIDS yang digunakan dalam penelitian ini diformulasikan berdasarkan data pangsa pengeluaran, variabel harga dan karakteristik rumah tangga. Hasil analisis diharapkan dapat menjawab faktor-faktor yang mempengaruhi permintaan pangan dan respon permintaan pangan rumah tangga sehingga dapat memberikan rekomendasi kebijakan bagi upaya peningkatan konsumsi rumah tangga di kedua provinsi terutama di daerah yang rawan pangan.

TABEL 3. RATA-RATA PANGSA PENGELUARAN PANGAN DI NTT DAN KALTIM, 2017

\begin{tabular}{lllc}
\hline \multicolumn{1}{c}{ Nama Komoditas } & NTT & Nama Komoditas & Kaltim \\
\hline Gula Pasir & 0,04 & Daging Ayam Ras & 0,06 \\
Minyak Goreng & 0,04 & Telur Ayam Ras & 0,06 \\
Mie Instant & 0,02 & Minyak Goreng & 0,05 \\
Pisang & 0,02 & Mie Instant & 0,04 \\
Telur Ayam Ras & 0,02 & Gula Pasir & 0,04 \\
Bawang Merah & 0,02 & Bawang Merah & 0,03 \\
Ikan Tongkol & 0,02 & Ikan Tongkol & 0,02 \\
Daging Ayam Ras & 0,01 & Tempe & 0,02 \\
Daging Sapi & 0,01 & Pisang & 0,02 \\
Tahu & 0,01 & Tahu & 0,02 \\
Tempe & 0,01 & Apel & 0,01 \\
Vetsin & 0,01 & Daging Sapi & 0,01 \\
Cabai Merah & 0,01 & Cabai Merah & 0,01 \\
Apel & 0,01 & Vetsin & 0,01 \\
Kedelai & 0,01 & Kedelai & 0,01
\end{tabular}

Sumber: Badan Pusat Statistik, (diolah)

\section{DIVERSIFIKASI PANGAN}

Tingkat diversifikasi pangan dari hasil olahan data menunjukkan bahwa rata-rata tingkat diversifikasi di Kaltim sebesar 0,76 yang berarti bahwa sekitar 76 persen komoditas dikonsumsi oleh rumah tangga (Tabel 4). Tingkat diversifikasi pangan antara daerah di perdesaan dan di perkotaan Kaltim juga hampir sama, di mana indeks bery di perkotaan dan di perdesaan hanya selisih sebesar 0,02. NTT memiliki rata-rata tingkat diversifikasi pangan yang lebih rendah sebesar 0,10 dibandingkan dengan Kaltim. Untuk tingkat diversifikasi pangan antara perdesaan dan perkotaan juga lebih timpang, dimana selisih nilainya sebesar 0,05 lebih tinggi di perkotaan.

TABEL 4. RATA-RATA TINGKAT DIVERSIFIKASI PANGAN DI NTT DAN KALTIM, 2017

\begin{tabular}{|c|c|c|}
\hline Uraian & NTा & Kaltim \\
\hline Provinsi & 0,67 & 0,77 \\
\hline Perdesaan & 0,66 & 0,76 \\
\hline Perkotaan & 0,72 & 0,78 \\
\hline
\end{tabular}

Sumber : Badan Pusat Statistik, (diolah)

Perbedaan tingkat diversifikasi pangan yang lebih rendah di desa dikarenakan ketersediaan variasi 
jenis makanan lebih banyak di daerah perkotaan. Hal ini juga disebabkan keterbukaan perdagangan dan fasilitas publik di perkotaan lebih baik dibandingkan di perdesaan. Hal ini menyebabkan akses terhadap pangan yang lebih mudah di perkotaan dibandingkan di perdesaan.

\section{HASIL PENGOLAHAN MENGGUNAKAN MODEL AIDS}

Beberapa penelitian pola konsumsi yang menggunakan raw data SUSENAS rata-rata memiliki nilai koefisien determinasi di bawah 50 persen yang rendah antara lain penelitian model permintaan oleh Miranti et al. (2016), Nugroho dan Suparyono (2016). Rendahnya koefisien determinasi dapat disebabkan karena data yang digunakan adalah data cross section yang keberagamannya sangat tinggi (Gujarati 2003). Hasil olah data juga menunjukkan, dari 667 koefisien hanya 307 atau hampir 50 persen diantaranya yang signifikan, sehingga hanya hampir 50 persen variabel bebas saja yang secara bersama-sama dalam model berpengaruh nyata dalam menentukan proporsi pengeluaran untuk semua komoditas pangan.

\section{ANALISIS ELASTISITAS PENGELUARAN PANGAN DAN PENDAPATAN}

Nilai elastisitas komoditas pangan dalam model permintaan adalah salah satu hal penting dalam suatu penelitian terhadap pola konsumsi. Elastisitas digunakan untuk mengetahui karakteristik komoditas pangan terhadap perubahan pendapatan rumah tangga dan harga pangan. Nilai elastisitas pengeluaran digunakan untuk mengetahui respons dari perubahan permintaan yang disebabkan oleh perubahan pengeluaran rumah tangga untuk pangan. Angka elastisitas pendapatan digunakan untuk melihat perubahan permintaan yang disebabkan oleh perubahan pengeluaran total/pendapatan. Hasil perhitungan elastisitas pengeluaran dan pendapatan ditampilkan dalam Tabel 5.

Berdasarkan nilai elastisitas pendapatan, seluruh komoditas merupakan barang normal. Komoditas apel merupakan komoditas paling responsif di NTT, sebaliknya untuk gula pasir dan mie instant termasuk ke dalam komoditas yang kurang responsif yang ditunjukkan dengan nilai elastisitas pendapatan kurang dari \pm 1 . Untuk Kaltim komoditas yang responsif adalah daging sapi, dan apel. Jika dilihat dari model permintaan, apel memiliki nilai elastisitas yang tinggi dan dapat diartikan konsumsi komoditas tersebut lebih banyak dikonsumsi oleh rumah tangga dengan pendapatan per kapita tinggi. Oleh karena itu, apel dapat dikategorikan sebagai barang mewah, dimana peningkatan pendapatan rumah tangga akan meningkatkan permintaan terhadap apel. Selain itu, dapat disimpulkan apabila terjadi peningkatan pendapatan maka rumah tangga di NTT akan cenderung meningkatkan konsumsi apel, daging sapi, dan daging ayam ras dibandingkan komoditas lainnya

\section{TABEL 5. NILAI ELASTISITAS PENGELUARAN PANGAN DAN PENGELUARAN} TOTAL/PENDAPATAN

\begin{tabular}{|c|c|c|c|c|}
\hline \multirow[b]{2}{*}{ Komoditas } & \multicolumn{2}{|c|}{ NTT } & \multicolumn{2}{|c|}{ Kaltim } \\
\hline & $\begin{array}{c}\text { Pengeluaran } \\
\text { Pangan }\end{array}$ & $\begin{array}{c}\text { Pengeluaran } \\
\text { Total/ } \\
\text { Pendapatan }\end{array}$ & $\begin{array}{c}\text { Pengeluaran } \\
\text { Pangan }\end{array}$ & $\begin{array}{c}\text { Pengeluaran } \\
\text { Total/ } \\
\text { Pendapatan }\end{array}$ \\
\hline Ikan Tongkol & 2,28 & 1,62 & 1,46 & 0,88 \\
\hline Daging Sapi & 5,63 & 4,01 & 7,61 & 4,62 \\
\hline $\begin{array}{l}\text { Daging Ayam } \\
\text { Ras }\end{array}$ & 5,18 & 3,68 & 2,53 & 1,53 \\
\hline Telur Ayam Ras & 2,90 & 2,06 & 0,87 & 0,53 \\
\hline Bawang Merah & 2,16 & 1,54 & 1,13 & 0,69 \\
\hline Cabai Merah & 2,80 & 1,99 & 2,26 & 1,37 \\
\hline Kedelai & 1,86 & 1,32 & 1,17 & 0,71 \\
\hline Tahu & 3,68 & 2,62 & 1,16 & 0,70 \\
\hline Tempe & 3,75 & 2,67 & 1,12 & 0,68 \\
\hline Apel & 10,35 & 7,37 & 5,65 & 3,43 \\
\hline Pisang & 2,17 & 1,54 & 1,51 & 0,91 \\
\hline Minyak Goreng & 1,87 & 1,33 & 0,93 & 0,56 \\
\hline Gula Pasir & 1,02 & 0,73 & 0,49 & 0,30 \\
\hline Vetsin & 2,01 & 1,42 & $-2,96$ & $-1,79$ \\
\hline Mie Instant & 1,39 & 0,98 & 0,35 & 0,21 \\
\hline
\end{tabular}

Sumber : Badan Pusat Statistik, (diolah)

\section{ELASTISITAS HARGA SENDIRI KOMODITAS SUMBER PROTEIN HEWANI DAN NABATI DI NTT}

Nilai elastisitas harga untuk semua komoditas sumber protein hewani dan nabati di NTT memiliki nilai negatif sesuai dengan teori permintaan. besaran nilai elastisitas harga juga menunjukkan bahwa komoditas sumber protein hewani dan nabati di NTT bersifat elastis. Dari Tabel 6 dapat diketahui bahwa di NTT, daging sapi memiliki nilai elastisitas harga sendiri paling elastis yaitu sebesar $-3,24$. Hal ini dapat diartikan jika terjadi kenaikan harga daging sapi 
sebesar 10 persen maka akan terjadi peningkatan permintaan terhadap daging sapi sebesar 32 persen. Hasil elastisitas tersebut sama dengan Miranti (2016) di mana elastisitas harga sendiri daging sapi merupakan yang paling elastis dengan nilai sebesar 1.956. Penelitian Irawan (2002) menghasilkan elastisitas harga sendiri yang seluruhnya bernilai negatif dan bersifat inelastis pada komoditas ikan, daging ternak, daging unggas, dan telur. Penelitian Arthatiani (2018) untuk semua komoditas ikan menghasilkan elastisitas harga sendiri yang negatif. Penelitian dengan hasil berbeda yaitu Rizal (2018) dengan nilai elastisitas harga ikan laut tangkapan di Bandung sebesar -1.932 .

\section{ELASTISITAS HARGA SILANG KOMODITAS SUMBER PROTEIN HEWANI DAN NABATI DI NTT}

Ikan tongkol hanya memiliki hubungan substitusi dengan telur ayam ras sedangkan dengan komoditas sumber protein lainnya bersifat komplemen. Kenaikan harga ikan tongkol berpotensi merubah rumah tangga untuk beralih ke konsumsi telur ayam ras.

\section{ELASTISITAS HARGA SENDIRI KOMODITAS SUMBER PROTEIN HEWANI DAN NABATI DI KALTIM}

Elastisitas harga sendiri dan harga silang di Kaltim dapat dilihat pada tabel 6. Komoditas kedelai merupakan komoditas dengan elastisitas harga sendiri paling elastis yaitu sebesar 7,08. Hal ini dapat diartikan jika terjadi kenaikan harga kedelai sebesar 10 persen maka akan terjadi peningkatan permintaan terhadap kedelai sebesar 70 persen.

Selain kedelai, daging sapi juga memiliki elastisitas harga sendiri yang bernilai positif sebesar 0,36 Nilai elastisitas harga sendiri yang memiliki arah positif di Kaltim untuk komoditas sumber protein hewani dan nabati adalah daging sapi dan kedelai. Diduga komoditas-komoditas tersebut merupakan barang veblen, di mana konsumsi komoditas tersebut meningkat seiring kenaikan pendapatan. Hal tersebut ditunjukkan dari pangsa pengeluaran komoditaskomoditas tersebut hanya dikonsumsi oleh golongan 6 ke atas yaitu golongan dengan pendapatan perkapita 750.000 rupiah ke atas. Argumen serupa terdapat pada penelitian Schachmurove dalam Veblen (2012), dan Leibenstein (1950) bahwa barang mewah atau Veblen, kenaikan harganya membuat mereka lebih diinginkan di mata beberapa konsumen. Tingginya harga meningkatkan status sosial yang tinggi jika mengkonsumsi barang-barang tersebut.

Hasil elastisitas harga sendiri bertanda positif juga terdapat pada penelitian (Shachmurove et al. 2012) yang menemukan bahwa terjadi hubungan positif antara harga dan jumlah barang yangdikonsumsi untuk komoditas kentang dan roti tahun 1990 dan 1992 di Rusia, di mana harga relatif kentang meningkat 36 persen dan jumlah yang dikonsumsi meningkat 13 persen, sedangkan harga relatif roti meningkat 30 persen dan jumlah relatif dikonsumsi meningkat 29 persen.

Dari Tabel 6 dapat diketahui bahwa di Kaltim, kedelai memiliki nilai elastisitas harga sendiri paling tinggi yaitu sebesar 7,08, sedangkan yang paling rendah adalah daging sapi sebesar 0,36. Daging sapi, daging ayam ras, dan telur ayam ras merupakan komoditas yang memiliki elastisitas harga sendiri yang bersifat inelastis, di mana penurunan permintaan tidak sebesar dengan kenaikan harganya. Hal tersebut menunjukkan bahwa rumah tangga di Kaltim memiliki preferensi yang tinggi terhadap konsumsi ketiga komoditas tersebut.

\section{ELASTISITAS HARGA SILANG KOMODITAS SUMBER PROTEIN HEWANI DAN NABATI DI KALTIM}

Elastistitas harga silang kedelai terhadap permintaan daging sapi merupakan yang paling responsif yaitu sebesar -12,32. Hal tersebut menunjukkan kedua komoditas tersebut merupakan barang mewah, dan sedikit rumah tangga yang mengkonsumsi sehingga pengaruh perubahan yang ditimbulkan sangat besar. 
TABEL 6. NILAI ELASTISITAS HARGA SENDIRI DAN HARGA SILANG UNTUK KOMODITAS SUMBER PROTEIN HEWANI DAN NABATI

\begin{tabular}{|c|c|c|c|c|c|c|c|c|c|c|c|c|c|c|}
\hline \multirow{3}{*}{ Jumlah Permintaan } & \multicolumn{14}{|c|}{ Harga Pangan } \\
\hline & \multicolumn{2}{|c|}{ Ikan Tongkol } & \multicolumn{2}{|c|}{ Daging Sapi } & \multicolumn{2}{|c|}{ Daging Ayam Ras } & \multicolumn{2}{|c|}{ Telur Ayam Ras } & \multicolumn{2}{|c|}{ Kedelai } & \multicolumn{2}{|c|}{ Tahu } & \multicolumn{2}{|c|}{ Tempe } \\
\hline & NTT & Koltim & NTा & Kaltim & NTा & Kaltim & NTा & Kaltim & NT & Kaltim & NTT & Kaltim & NTा & Kaltim \\
\hline |kan Tongkol & $-1,67$ & $-1,11$ & $-0,40$ & 0,60 & $-0,03$ & 0,35 & 0,03 & $-0,15$ & $-0,05$ & 0,03 & $-0,02$ & $-0,48$ & $-0,11$ & $-0,28$ \\
\hline Daging Sapi & $-1,25$ & 1,57 & $-3,24$ & 0,36 & 1,32 & $-2,42$ & 0,27 & $-3,51$ & 0,10 & $-0,16$ & $-0,22$ & 0,55 & $-0,15$ & 0,71 \\
\hline Daging Ayam Ras & $-0,01$ & 0,11 & 0,22 & $-0,30$ & $-1,13$ & $-0,81$ & $-0,01$ & $-0,12$ & $-0,00$ & 0,00 & 0,01 & 0,00 & $-0,02$ & $-0,01$ \\
\hline Telur Ayam Ras & 0,02 & $-0,05$ & 0,08 & $-0,48$ & 0,00 & $-0,02$ & $-1,21$ & $-0,66$ & 0,02 & 0,00 & $-0,04$ & $-0,05$ & 0,01 & $-0,04$ \\
\hline Bawang Merah & 0,07 & 0,26 & $-0,13$ & $-0,28$ & $-0,14$ & $-0,32$ & $-0,05$ & $-0,02$ & 0,00 & $-0,01$ & $-0,06$ & 0,03 & $-0,06$ & 0,11 \\
\hline Cabai Merah & $-0,27$ & 0,33 & 0,58 & $-1,53$ & 0,53 & $-0,76$ & $-0,18$ & $-0,03$ & $-0,02$ & 0,02 & $-0,08$ & $-0,05$ & 0,36 & 0,36 \\
\hline Kedelai & $-11,74$ & 6,14 & 7,69 & $-12,32$ & $-0,58$ & 1,74 & 9,13 & 1,65 & $-2,96$ & 7,08 & 5,14 & 1,02 & $-1,78$ & 3,37 \\
\hline Tahu & $-0,03$ & $-0,57$ & $-0,06$ & 0,29 & 0,03 & 0,09 & $-0,13$ & $-0,16$ & 0,03 & 0,01 & $-1,07$ & $-1,41$ & $-0,08$ & 0,07 \\
\hline Tempe & $-0,12$ & $-0,30$ & $-0,03$ & 0,33 & $-0,06$ & 0,08 & 0,00 & $-0,10$ & $-0,01$ & 0,02 & $-0,07$ & 0,06 & $-1,09$ & $-2,09$ \\
\hline Apel & $-0,05$ & $-0,45$ & $-0,19$ & 0,21 & 1,08 & $-1,07$ & $-0,37$ & 0,10 & 0,08 & 0,01 & $-0,02$ & $-0,68$ & $-0,19$ & 0,42 \\
\hline Pisang & 0,09 & $-0,71$ & 0,04 & 0,30 & $-0,64$ & 0,21 & $-0,16$ & $-0,23$ & 0,01 & 0,01 & $-0,02$ & $-0,06$ & $-0,02$ & $-0,12$ \\
\hline Minyak Goreng & $-0,09$ & 0,15 & $-0,07$ & $-0,03$ & $-0,14$ & $-0,19$ & 0,00 & 0,10 & 0,01 & 0,02 & $-0,01$ & 0,02 & 0,01 & 0,07 \\
\hline Gula Pasir & 0,13 & 0,47 & $-0,38$ & $-0,07$ & $-0,44$ & $-0,32$ & 0,16 & 0,43 & $-0,01$ & $-0,04$ & 0,05 & $-0,08$ & $-0,07$ & $-0,10$ \\
\hline Vetsin & 1,01 & 3,72 & $-2,97$ & $-0,59$ & $-3,52$ & $-2,53$ & 1,26 & 3,41 & $-0,10$ & $-0,34$ & 0,38 & $-0,61$ & $-0,53$ & $-0,77$ \\
\hline Mie Instant & $-0,16$ & 0,21 & 0,04 & $-0,14$ & $-0,01$ & 0,21 & 0,02 & $-0,04$ & 0,00 & $-0,01$ & $-0,06$ & 0,14 & $-0,04$ & $-0,06$ \\
\hline
\end{tabular}

Sumber: Badan Pusat Statistik (diolah)

\section{ELASTISITAS HARGA SENDIRI KOMODITAS SUMBER VITAMIN DAN MINERAL}

Komoditas apel merupakan satu-satunya komoditas yang memiliki nilai elastisitas harga sendirinya bernilai positif dan inelastis yaitu sebesar 0,25 di Kaltim pada kelompok komoditas sumber vitamin dan mineral (Tabel 7). Elastisitas harga sendiri bernilai positif terdapat pada penelitian Schachmurove dalam Veblen (2012), dan Leibenstein (1950) bahwa barang mewah atau Veblen, kenaikan harganya membuat mereka lebih diinginkan di mata beberapa konsumen. Tingginya harga meningkatkan status sosial yang tinggi jika mengkonsumsi barangbarang tersebut.

Komoditas paling responsif baik di NTT maupun Kaltim adalah cabai merah, di mana nilai elastisitas harga sendirinya sebesar $-1,40$ dan $-1,79$. Hal ini menjadi menarik karena cabai merah merupakan komoditas yang sehari-hari dikonsumsi, namun nilai elastisitasnya bersifat elastis. Hasil elastisitas harga sendiri untuk bawang merah dan cabai merah yang bernilai negatif juga diperoleh dari penelitian Suroso et al. (2014) di pulau jawa dengan nilai elastisitas masing-masing sebesar -0,83 dan -0,77.
TABEL 7. NILAI ELASTISITAS HARGA SENDIRI DAN HARGA SILANG UNTUK KOMODITAS SUMBER VITAMIN DAN MINERAL

\begin{tabular}{|c|c|c|c|c|c|c|c|c|}
\hline \multirow[b]{3}{*}{ Jumlah Permintaan } & \multicolumn{8}{|c|}{ Harga Pangan } \\
\hline & \multicolumn{4}{|c|}{ NTT } & \multicolumn{4}{|c|}{ Kaltim } \\
\hline & $\begin{array}{l}\text { 동 } \\
\text { 旁 } \\
\text { 듬 } \\
\text { 言 }\end{array}$ & 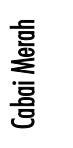 & 昰 & 몸 & $\begin{array}{l}\text { 등 } \\
\text { 읗 } \\
\text { 홍 }\end{array}$ & $\begin{array}{l}\text { 등 } \\
\text { 离 } \\
\text { 家 }\end{array}$ & 远 & 몸 \\
\hline Ikan Tongkol & 0,08 & $-0,08$ & $-0,01$ & 0,09 & 0,31 & 0,10 & $-0,15$ & $-0,64$ \\
\hline Daging Sapi & $-0,58$ & 0,46 & $-0,27$ & 0,01 & $-1,20$ & $-1,34$ & 0,24 & 0,63 \\
\hline Daging Ayam Ras & $-0,08$ & 0,06 & 0,20 & $-0,23$ & $-0,21$ & $-0,10$ & $-0,16$ & 0,05 \\
\hline Telur Ayam Ras & $-0,03$ & $-0,02$ & $-0,06$ & $-0,05$ & $-0,00$ & 0,01 & 0,07 & $-0,08$ \\
\hline Bawang Merah & $-1,02$ & $-0,07$ & $-0,01$ & 0,03 & $-1,41$ & $-0,14$ & 0,05 & 0,00 \\
\hline Cabai Merah & $-0,27$ & $-1,40$ & 0,15 & $-0,37$ & $-0,63$ & $-1,79$ & $-0,22$ & 0,07 \\
\hline Kedelai & 1,25 & $-1,57$ & 7,26 & 1,72 & $-2,04$ & 1,30 & 0,95 & 1,79 \\
\hline Tahu & $-0,10$ & $-0,03$ & $-0,00$ & $-0,02$ & 0,04 & $-0,01$ & $-0,30$ & $-0,05$ \\
\hline Tempe & $-0,09$ & 0,12 & $-0,08$ & $-0,01$ & 0,15 & 0,13 & 0,25 & $-0,10$ \\
\hline Apel & $-0,06$ & 0,10 & $-1,09$ & $-0,12$ & $-0,01$ & $-0,17$ & 0,25 & $-0,15$ \\
\hline Pisang & 0,02 & $-0,13$ & $-0,05$ & $-1,03$ & $-0,01$ & 0,03 & $-0,02$ & $-1,57$ \\
\hline Minyak Goreng & $-0,05$ & $-0,05$ & $-0,06$ & $-0,05$ & $-0,16$ & 0,08 & $-0,00$ & $-0,06$ \\
\hline Gula Pasir & 0,14 & 0,06 & $-0,03$ & 0,24 & 0,05 & 0,00 & $-0,22$ & $-0,04$ \\
\hline Vetsin & 1,10 & 0,47 & $-0,25$ & 1,87 & 0,41 & $-0,04$ & $-1,76$ & $-0,30$ \\
\hline Mie Instant & $-0,03$ & 0,04 & 0,17 & 0,04 & $-0,05$ & $-0,14$ & $-0,04$ & 0,36 \\
\hline
\end{tabular}

Sumber : Badan Pusat Statistik (diolah)

Komoditas yang tidak responsif adalah komoditas apel di Kaltim, di mana nilai elastisitas harga sendirinya bersifat inelastis sebesar 0,25. Hal tersebut menunjukkan bahwa apel merupakan 
komoditas pokok yang sering dikonsumsi rumah tangga di Kaltim. Hasil elastisitas harga sendiri untuk apel juga menunjukkan bahwa diversifikasi pangan yang terjadi di Kaltim terjadi pada konsumsi buahbuahan. Komoditas apel menjadi pilihan rumah tangga di Kaltim ketika harga komoditas apel tidak mengalami kenaikan yang dapat menyebabkan kemampuan mendiversifikasi pangan rumah tangga menurun. Pola konsumsi rumah tangga yang mengkonsumsi apel menunjukkan pola konsumsi yang sehat, di mana buah-buahan banyak mengandung nutrisi yang baik untuk tubuh.

\section{ELASTISITAS HARGA SILANG KOMODITAS SUMBER VITAMIN DAN MINERAL}

Cabai merah memiliki hubungan komplemen dengan bawang merah sesuai dengan kebiasaan rumah tangga di Indonesia bahwa kedua komoditas tersebut merupakan bumbu pelengkap dalam masakan. Pisang juga memiliki hubungan komplemen dengan apel. Hasil elastisitas harga silang cabai merah terhadap permintaan bawang merah bernilai negatif sebesar 0,07 di NTT dan -0,14 di Kaltim (Tabel 7). Hasil yang sama juga diperoleh suroso et al. (2014) di Yogyakarta yang menghasilkan nilai elastisitas harga silang cabai merah terhadap permintaan bawang merah sebesar $-0,02$.

\section{ELASTISITAS HARGA SENDIRI KOMODITAS MAKANAN INSTAN DAN SUMBER LEMAK}

Dari Tabel 8 dapat diketahui bahwa vetsin memiliki nilai elastisitas harga sendiri paling elastis yaitu sebesar -2,73 di NTT dan -7,51 di Kaltim. Hal ini dapat diartikan jika terjadi kenaikan harga vetsin sebesar 10 persen maka akan terjadi penurunan permintaan terhadap vetsin sebesar 27 persen di NTT dan 75 persen di Kaltim. Hal ini menunjukkan suatu yang baik karena berarti vetsin tidak menjadi komoditas pokok. Sebagaimana kita ketahui bahwa vetsin tidak baik bagi kesehatan jika kita mengkonsumsinya. Elastisitas harga sendiri untuk komoditas minyak goreng di NTT sebesar -0,84 yang berarti inelastis terhadap perubahan harga. Penelitian Irawan (2002) juga menghasilkan elastisitas harga sendiri untuk komoditas minyak goreng yang memiliki arah negatif yang sama yaitu sebesar $-0,082$ di perdesaan dan -0,085 di perkotaan.

\begin{tabular}{|c|c|c|c|c|c|c|c|c|}
\hline \multirow[b]{3}{*}{ Jumlah Permintaan } & \multicolumn{8}{|c|}{ Harga Pangan } \\
\hline & \multicolumn{4}{|c|}{ NTा } & \multicolumn{4}{|c|}{ Kaltim } \\
\hline & 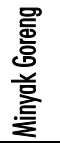 & $\begin{array}{l}\text { 咅 } \\
\text { 흠 }\end{array}$ & 毫 & 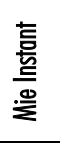 & 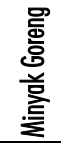 & $\begin{array}{l}\text { 袅 } \\
\text { 음 }\end{array}$ & 亳 & 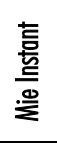 \\
\hline Ikan Tongkol & $-0,21$ & 0,16 & $-0,09$ & $-0,31$ & 0,29 & 0,70 & 0,05 & 0,30 \\
\hline Daging Sapi & $-0,63$ & $-1,88$ & 0,05 & 0,01 & $-0,53$ & $-0,62$ & 0,19 & $-1,01$ \\
\hline Daging Ayam Ras & $-0,13$ & $-0,32$ & $-0,02$ & $-0,04$ & $-0,26$ & $-0,30$ & 0,00 & 0,04 \\
\hline Telur Ayam Ras & 0,00 & 0,08 & 0,02 & 0,00 & 0,10 & 0,28 & 0,02 & $-0,06$ \\
\hline Bawang Merah & $-0,10$ & 0,15 & $-0,00$ & $-0,07$ & $-0,28$ & 0,04 & 0,01 & $-0,11$ \\
\hline Cabai Merah & $-0,34$ & 0,28 & 0,04 & 0,23 & 0,45 & $-0,10$ & $-0,07$ & $-0,89$ \\
\hline Kedelai & 6,40 & $-4,27$ & $-0,06$ & 0,24 & 7,67 & $-14,61$ & $-3,18$ & $-3,67$ \\
\hline Tahu & $-0,05$ & 0,05 & $-0,01$ & $-0,16$ & 0,04 & $-0,17$ & 0,09 & 0,26 \\
\hline Tempe & 0,00 & $-0,15$ & $-0,03$ & $-0,11$ & 0,15 & $-0,19$ & $-0,14$ & $-0,14$ \\
\hline Apel & $-0,33$ & $-0,18$ & 0,09 & 0,60 & $-0,27$ & $-1,02$ & 0,19 & $-0,41$ \\
\hline Pisang & $-0,15$ & 0,36 & $-0,01$ & 0,03 & $-0,16$ & $-0,11$ & $-0,04$ & 0,62 \\
\hline Minyak Goreng & $-0,84$ & 0,06 & 0,01 & 0,01 & $-1,29$ & $-0,09$ & 0,00 & $-0,33$ \\
\hline Gula Pasir & 0,11 & $-1,22$ & 0,04 & 0,01 & $-0,10$ & $-1,81$ & $-0,04$ & $-0,03$ \\
\hline Vetsin & 0,87 & $-0,68$ & $-2,73$ & 0,09 & $-0,79$ & 5,24 & $-7,51$ & $-0,22$ \\
\hline Mie Instant & 0,03 & 0,00 & 0,01 & $-1,12$ & $-0,38$ & $-0,02$ & 0,02 & $-1,44$ \\
\hline
\end{tabular}

Sumber : Badan Pusat Statistik (diolah)

\section{ELASTISITAS HARGA SILANG KOMODITAS MAKANAN INSTAN DAN SUMBER LEMAK}

Elastisitas harga silang paling tinggi di Kaltim adalah untuk perubahan harga komoditas gula pasir terhadap permintaan vetsin yaitu sebesar 5,24, di mana kenaikan harga gula pasir akan meningkatkan permintaan terhadap vetsin (Tabel 8). Elastisitas perubahan harga minyak goreng terhadap permintaan gula pasir sebesar 0,87 merupakan elastisitas silang yang paling tinggi di Kaltim. Minyak goreng dan gula pasir merupakan komoditas bahan baku yang banyak dibutuhkan sebagai pembuatan makanan jadi. Penelitian Puspita et al. (2019) menemukan bahwa konsumsi lemak pada anak-anak melebihi standar. Hal ini diperoleh dari konsumsi jajanan yang berasal dari makanan yang digoreng.

\section{TEMUAN LAINNYA}

Nilai elastisitas harga sendiri yang memiliki arah positif di Kaltim adalah komoditas daging sapi, kedelai, dan apel. Komoditas-komoditas tersebut diduga merupakan barang veblen, dimana konsumsi komoditas tersebut meningkat seiring kenaikan pendapatan. Hal tersebut ditunjukkan dari pangsa 
pengeluaran komoditas-komoditas tersebut hanya dikonsumsi oleh golongan 4 ke atas yaitu golongan dengan pendapatan perkapita 300,000 rupiah ke atas. Penelitian Veblen (1911), Leibenstein (1950) menyatakan bahwa barang mewah atau Veblen, kenaikan harganya membuat mereka lebih diinginkan di mata beberapa konsumen. Tingginya harga meningkatkan status sosial yang tinggi jika mengkonsumsi barang-barang tersebut. Seluruh komoditas yang memiliki elastisitas harga bernilai positif semuanya adalah produk pangan yang sebagian besar diperoleh dari impor untuk pemenuhan kebutuhan dalam negeri.

Jumlah anggota rumah tangga dan perbedaan wilayah perdesaan maupun perkotaan tidak berpengaruh terhadap konsumsi suatu komoditas. Hal tersebut dapat dilihat dari nilai parameter dugaan. NTT maupun Kaltim untuk jumlah anggota rumah tangga dan dummy wilayah memiliki nilai parameter dugaan rata-rata $<0.01$. Hasil yang berbeda diperoleh Purwaningsih et al. (2015) yang menemukan jumlah anggota rumahtangga berpengaruh signifikan terhadap aksesibilitas pangan rumah tangga.

\section{KESIMPULAN}

Provinsi dengan rata-rata pendapatan per kapita rumahtangga yang tinggi memiliki tingkat diversifikasi pangan yang lebih tinggi. Provinsi tahan pangan memiliki nilai pangsa pengeluaran terhadap makanan non karbohidrat yang lebih tinggi dibandingkan provinsi rawan pangan. Harga pangan (baik harga sendiri maupun harga silang), pendapatan/pengeluaran, jenis wilayah dan jumlah anggota rumahtangga terbukti berpengaruh terhadap permintaan pangan. Berdasarkan nilai elastisitas harga sendiri diketahui bahwa ada 3 (tiga) komoditas yang memiliki nilai elastisitas permintaan yang inelastis untuk NTT yaitu apel, pisang, dan minyak goreng, sedangkan Kaltim hanya 2 (dua) komoditas yaitu daging ayam ras, dan apel. Pola konsumsi pangan rumah tangga di NTT lebih dipengaruhi oleh perubahan pendapatan, sedangkan Kaltim oleh perubahan harga. Hal ini ditunjukkan dengan banyaknya komoditas pangan yang memiliki nilai elastisitas pendapatan yang lebih tinggi dibandingkan dengan elastisitas harga di NTT, sedangkan Kaltim sebaliknya. Jumlah anggota rumah tangga tidak berpengaruh terhadap tingkat diversifikasi pangan rumah tangga baik di Kaltim maupun di NTT.

\section{UCAPAN TERIMA KASIH}

Ucapan terima kasih penulis sampaikan kepada Badan Pusat Statistik yang memberi kesempatan, dana, dan fasilitas dalam pendidikan program magister penulis. Penelitian ini merupakan bagian dari tesis di Jurusan Ilmu Ekonomi Institut Pertanian Bogor dan bagian lain dari tesis ini yaitu untuk komoditas sumber karbohidrat sudah dibuatkan jurnal tersendiri.

\section{DAFTAR PUSTAKA}

Ariani M. (2010). Analisis Konsumsi Pangan Tingkat Masyarakat Mendukung Pencapaian Diversifikasi Pangan. Jurnal Gizi Indonesia . 33(1):20-28. https://ejournal.persagi.org/inde x.php/Gizi_Indon/article/download/84/81

Arthatiani FY, Kusnadi N, Harianto. (2018). Analisis Pola Konsumsi dan Model Permintaan Ikan Menurut Karakteristik Rumah Tangga Di Indonesia. J. Sosek KP 13 (1): 73-86. http:// ejournal-balitbang.kkp.go.id/index.php /sosek/article/view/6967

Badan Pusat Statistik. (2017). Publikasi Pengeluaran untuk Konsumsi Penduduk Indonesia per Provinsi. BPS-Statistics Indonesia.

Deaton A, Muellbauer J. (1980). An Almost Ideal Demand System. Jstor. 70(3):312-326. http:// www.jstor.org/stable/1805222.

Faharuddin, Mulyana A, Yamin M, Yunita. (2015). Analisis Pola Konsumsi di Sumatera Selatan:Pendekatan Quadratic Almost Ideal System. Jurnal Agro Ekonomi. 33(2):123140.http://eprints.unsri.ac.id/6879/

Fortunika SO, Istiyanti E, Sriyadi. (2017). Kontribusi Sektor Pertanian Terhadap Perekonomian Kabupaten Banjarnegara. AGRARIS: Journal of Agribusiness and Rural Development Research, 3(2), 119-127.. https://doi.org/10. 18196/agr.3252

Gujarati.(2003). Basic Econometrics (Fourth Edition) The Mc.Graw-Hill Companies.

Headey DD, Martin WJ. (2016). The Impact of Food Prices on Poverty and Food Security. https:// doi.org/10.1146/annurev-resource-100815095303 
Irawan B. (2002). Elastisitas konsumsi kalori dan protein di tingkat rumah tangga. JAE. 20 (1): 25- 47. http://repository.pertanian.go.id/ handle/123456789/394

Kementerian Perdagangan. (2013). Laporan Akhir Ananlisis Dinamika Konsumsi Pangan Masyarakat Indonesia. Pusat Kebijakan Perdagangan Dalam Negeri.

Leibenstein H. (1950). Bandwagon, Snob, and Veblen Effects in The Theory of Consumers' Demand. Quarterly Journal of Economics. 64:183207.http://www.jstor.org/stable/1882692

Matz JA, Kalkuhl M, Abegaz GA. (2015). The shortterm impact of price shocks on food security - Evidence from urban and rural Ethiopia. Food Security. 7(3): 657-679. doi: 10.1007 /s12571-015-0467-4.

Mauludyani AVR., Matianto D, Baliwati YF. (2008). Pola Konsumsi Dan Permintaan Pangan Pokok Berdasarkan Analisis Data Susenas 2005. Jurnal Gizi dan Pangan. 3 (2):101-117.http:// jai.ipb.ac.id/index.php/jgizipangan/article/vie w/4457

Miranti, Syaukat Y, Harianto. (2016). Pola Konsumsi Pangan Rumah Tangga di Provinsi Jawa Barat. JAE. 34 (1):67-80.http://dx.doi.org/10. 21082/jae.v34n1.2016.67-80

Nugroho S dan Suparyono SW. (2016). Pola Permintaan Daging Tingkat Rumah Tangga di Indonesia: Analisa Data Mikro 2013. Jurnal Ekonomi dan Pembangunan Indonesia. 16(1): 47-58.DOI: http://dx.doi.org/10.21002 /jepi.v16i1.668

Pangaribowo, Hanie E, Tsegai, Daniel. (2011). Food demand analysis of Indonesian households with particular attention to the poorest.ZEF Discussion Papers on Development Policy. No. 151. http://hdl.handle.net/10419/98222

Purwaningsih Y, Sutomo, Istiqomah N. (2015). Analisis Dampak Alih Fungsi Lahan terhadap Tingkat Ketahanan Pangan Rumah Tangga Petani di Karanganyar, Jawa Tengah. AGRARIS: Journal of Agribusiness and Rural Development Research, 1(2), 98-107. https://doi.org/10.18 $196 / 1213$

Rachman HPS, Ariani M. (2008). Penganekaragaman konsumsi pangan di Indonesia: Permasalahan dan implikasi untuk kebijakan dan program. Analisis Kebijakan Pertanian. 6(2): 140-154. http://repository.pertanian.go.id/handle/1234 56789/525

Riyani, Darsono, Ferichani M. (2018). Analisis Permintaan Ekspor Komoditas Pertanian Indonesia oleh Pasar Tiongkok. AGRARIS:
Journal of Agribusiness and Rural Development Research, 4(2), 120-128.. http: //journal.umy.ac.id/index.php/ag/article/view/ 4382

Rizal A, Aprilia L, Nurruhwati I, Nurhayati.(2018). The Elasticity of Demand for Catfish Products (Clarias sp.) in Bandung City of Indonesia. World Scientific News. 102 (18): 76-89. http://yadda.icm.edu.pl/yadda/element/bwme ta1 .element.psjd-5b1864d2-67f4-4b5093f5-03042e1084d6

Ruel MT. (2003). Operationalizing dietary diversity: a review of measurement issues and research priorities. Forum Penelitian Agro Ekonomi. 25 (1): 1 - 18. https://academic.oup.com/jn/articl e-abstract/133/11/3911S/4818042

Shachmurove Y, Szyrmer J. (2012). Giffen Goods in a Transition Economy: Subsistence Consumption in Russia. Frontiers in Finance and Economics. 8(2): 27-48. https://papers. ssrn.com/sol3/papers.cfm?abstract_id $=2012$ 482.

Suriani, Majid MSA. (2018). Analysis of food demand elasticity of rice for the poor in Aceh, Indonesia: An almost ideal demand system. DLSU Business \& Economics Review. 27(2): 179-189.: https://www.researchgate.net/pub lication/322939150

Suroso Al, Firdaus M, Savitri D. (2014). Demand for the Mai Vegetables in Java Island. ISSAAS. 20(2): 98-109. http://issaas.org/journal/v20/02/jour nal-issaas-v20n2-10-suroso_etal.pdf

Timmer CP. Falcon WP. Pearson SR. (1983). Food Policy Analysis. London (UK): The World Bank.https://fsi-live.s3.us-west-1.amazonaws .com/s3fs-public/Food_Policy_Analysis.pdf

Veblen, T. (1911). The Theory of the Leisure Class, London (GB): Allen \& Unwin.

Widodo AS, Wulandari R. (2016). Analisis Pola Konsumsi dan Tingkat Kerawanan Pangan Petani Lahan Kering di Kabupaten Gunungkidul (Studi Kasus di Desa Giritirto, Kecamatan Purwosari, Gunungkidul) AGRARIS: Journal of Agribusiness and Rural Development Research, 2(2), 161-167.. https ://doi.org/10.18196/agr.2237

Wijaya O. (2017). Strategi Pengembangan Komoditas Pangan Unggulan dalam Menunjang Ketahanan Pangan Wilayah (Studi Kasus di Kabupaten Batang, Propinsi Jawa Tengah). AGRARIS: Journal of Agribusiness and Rural Development Research, 3(1), 48-56.. https:// doi.org/10.18196/agr.3144 